\title{
Evaluation of squatter settlement transformations in Istanbul in the context of sustainability: a case study in Fikirtepe
}

\author{
Y. Alkiser Bregger \\ Faculty of Architecture, Istanbul Technical University, Turkey
}

\begin{abstract}
The urban transformation of consolidated squatter settlements in Turkey is being undertaken with disregard to their established socio-cultural and spatial identities. An example of this kind of transformation can be found in Fikirtepe, one of the oldest squatter settlements located in the Kadıköy neighbourhood, on the Asian side of Istanbul. We have carried out a study of this area, to analyse the on-going urban transformation processes and to suggest an alternative model which conforms to the requirements of sustainable development, in the social, economic and environmental sense. The study is based on published sources, legislation reviews, individual observations, and survey analysis performed by ITU architectural students within the elective graduate course, "Sustainable Transformation and Architecture" which took place in the autumn of 2015 at the Istanbul Technical University.

Keywords: urban transformation, squatter settlements, spatial identity, social pattern, sustainability.
\end{abstract}

\section{Introduction}

The creation of cities has been often the result of a transformation process from rural into urban areas. Mumford [1] asserted that powerful groups, such as traders, financiers, and landholders determined the growth of cities in the nineteenth century [1]. After the 1960s, the industrial sector was gradually replaced by the service sector [2], and more recently, the middle-upper class returned to the inner city and gentrified the slums in urban centres [3]. Since the 1980s, major political changes have taken place in a large number of developing countries, which have 
giving rise to urban transformations different to those experienced by the industrialized countries a century ago [4].

The urban context, which departs from the traditional notions of social interactions and leads to new behavioural patterns, is at the centre of social transformation. Cities exert an influence on the behaviour of residents [5]. In developing countries, squatter settlements are the expression of a transformation, which is both social and physical. Squatter settlements in large cities of developing countries were the result of migration waves and the lack of affordable housing. Also, natural hazards (earthquakes, flood and landslides) favoured the emergence of squatter settlements [6].

The aim of this paper is to evaluate current squatter settlement transformations in Turkey, their spatial qualities and social dynamics, taking the Fikirtepe settlement in Istanbul as a case study. The study was undertaken within a graduate course held in the autumn of 2015 in ITU, entitled "Sustainable Transformation and Architecture".

\section{Theoretical background}

Since the 1950s, squatter settlements have been steadily growing in Turkey, and many of them became consolidated residential areas over time. At some point, it became necessary to undergo transformation programmes to legalize these areas, and to improve their living conditions. These transformations, however, have been undertaken with total disregard of the sustainability requirements which are applied in other urban development processes.

\subsection{Squatter settlements}

Starting in the early 19th century, slum housing has spread throughout the industrial cities of the world. However, slums are not an exclusive problem of the industrial societies, but they can also occur in developing countries. In Turkey, a large number of people began to migrate from the rural areas to the big cities in the 1950s in search of employment and better living conditions [11, 12]. As a result, the self-built construction rapidly appeared. However, available statistics about the extent of squatter housing stocks are not very precise because of limited data. This has been further complicated by the amnesty legislation and resulting legalization of squatter housing.

In 1995, Turkey as a whole had 11 million people living in 2 million self-build houses representing 35 percent of the urban population. By 2002 of 11 million squatters living in 2.2 million squatter housing led to a decline in the ratio to 27 percent of the urban population in Turkey [12]. There were 3.75 million squatters living in 750,000 squatter houses in Istanbul in 1990 [13]. By the beginning of 2010 there were 4 million squatters living in 2 million squatter dwellings [14]. The number of squatters in population of Istanbul roughly decreased from 51 percent in 1990 to 30 percent by the beginning of 2010. The reason for the decrease in the squatter ratio was the legalization of occupied housing. 
At the beginning of the 1990s, poverty among newcomers, combined with a lack of available land, meant that the new residents could only rent houses in the squatter areas [15]. Duyar-Kienast [16] noted that by that time the proportion of tenants in these former "gecekondu" neighbourhoods had reached 80 percent. But besides the landlords of those rented apartments, other stakeholders such as developers and governmental agencies also wanted a share of the profit. This led to the construction of dense, high-rise buildings with insufficient open spaces, which have undermined the quality of life. In fact, many authors have identified some positive aspects in the squatter settlements such as the respect for the human scale, existence of gardens, low cost of the construction, sense of community and solidarity among people.

Squatter culture is very common in big cities in developing countries. The urban poor who settled in the periphery of the historic city centres have created a specific culture. Squatters consist of 6 percent of the urban population in developed countries but 78.2 percent in developing countries [6]. Rossi [17] considers "the relationship between the dwelling areas and the primary elements of a city as responsible for configurating that city in a specific way".

Rossi [17] and Smailes [18] describe unplanned cities as settlements growing and being adapted to discharged urban functions. Characteristics of unplanned cities appear during the growth process. Rossi [17] pointed out that traces of a city layout and its street design are not accidental in either planned or unplanned cities. For Rossi, the city is the locus of the collective memory, and this includes both planned and unplanned areas.

After the 1980s, and as a result of neo-liberal policies in developed countries, suburbs accelerated while squatter settlements grew in the less developed ones. Istanbul, which is considered both the heartland of the Turkish economy and a squatter housing paradise, entered into a process of accelerated, large-scale urban transformation in the following decades.

\subsection{Urban transformation/transition and sustainability}

Urban transformation involves both a process of renewal and regeneration. Strategies such as rehabilitation, revitalization, development, improvement, renaissance, gentrification, and conservation are part of urban transformation programmes. The evolution of regeneration strategies between 1950 and 1990 was comprehensively analysed by Roberts and Sykes [19] by building upon studies of Stöhr [20], Lichfield [21], Beswick and Tsenkova [22]. According to this analysis, reconstruction was embraced mostly in the 1950s, revitalization in the 1960s, renewal in the 1970s, redevelopment during the 1980s, and regeneration in the 1990s. By the 2000s, urban transformation was frequently on the agenda. These strategies tended to develop and move beyond requirements of current conditions and problems. For example, renewal required economic reconditioning and programs to promote employment [23].

Roberts and Kykes [19] argued that urban regeneration should not be circumscribed to renewal, development and revitalization. Rather, they proposed a comprehensive, cross-sectorial vision of urban transformation which includes economic, physical and environmental characteristics of a given area. Bosselmann 
[24], on the other hand, concluded that urban transformation focuses on urban morphology while urban renewal is more concerned with functionality.

Thorn [25] related urban transformation with globalization and everyday lives, while Decklerck [26] thought of architecture and urban transformation as powerful policy tools with which to improve social cohesion, quality of life, and the wellbeing in cities. The Chamber of Turkish Urban Planners in Istanbul [27] stated that the purpose of urban transformations is to produce urban projects which embrace the social, economic and spatial dimensions; projects to trigger a renewal, regeneration, rehabilitation, and redevelopment process in order to make problematic areas of a city healthier and more liveable.

Since the 1980s, sustainability has been a major theme in urban development. Özkan [28] claims that sustainability is one of the most important and widely accepted criteria for appraising environmental values, due to its importance in terms of cultural and historical awareness. However, sustainability has derived into a rhetoric about the positive values that represents for "nature and society" [29].

After the Rio de Janeiro Conference in 1992, sustainable urban transformation focused on achieving simultaneously economic development, social justice and environmental protection [30]. Roberts and Sykes [19] emphasized "sustainable development" when dealing with urban transformation. Yang [31] defined urban sustainability as the dynamic equilibrium of people's well-being and human-made and natural environments. Accordingly, during sustainable urban transformation, economic growth has the potential to increase social welfare and reduce environmental degradation.

In brief, urban transformation should be a sustainable physical, social, economic, and political process, which deals with physically and socially problematic areas in cities, by converting these areas into liveable, vivacious and quality places for present and future residents. This urban transformation needs to support competition among cities as they integrate into the global system. The results of an urban transformation can be both positive and negative. In this sense, the term "transformation" has a neutral meaning like renewal, while regeneration includes a more positive meaning. In the narrowest sense of these terms, transformation or renewal may not always be positive but regeneration is generally expected to imply a positive change.

\section{Urban transformation in Istanbul, Turkey}

After the big Marmara earthquake in 1999, Istanbul's municipality established the "Istanbul Metropolitan Planning and Urban Design Centre". Bayraktar [32], former Director of TOKI (Turkey's Housing Development Administration) and former Minister of Environment and Urbanization considered squatter housing as a waste of resources, which presents a city's transportation and infrastructure systems with many difficulties. He recommended that the squatter housing problem should be resolved swiftly by TOKI and the Metropolitan Municipalities.

Tekeli [33] classifies the urban transformation process in terms of earthquake risk areas, squatter settlements and ideological interest areas of government in 
Istanbul. Eraydin and Tasan-Kok [34] indicate that the government uses the city not only as an instrument for growth but also as a place to carry out socio-political transformation programmes.

TOKI, which is the only institution officially responsible for low-income housing in Turkey, represents a supply-oriented and centralized approach to housing issues [35]. It has focused on squatter settlements having the most earthquake risk and on preparing people for the future earthquakes [36]. Urban transformation programmes have focused on the provision of space by governmental authorities and on the proposal of megaprojects by the private developers; programmes which neglect the value of existing architectural and morphological patterns, the cultural heritage and the symbolic meaning of places for residents.

\subsection{Fikirtepe squatter settlement transformation project}

Fikirtepe is located within the boundaries of Kadıköy district in the Anatolian part of Istanbul (Figure 1), The earliest settlements in the Fikirtepe region date back to 5500 BC [37]. Currently, it has about 50,000 to 70,000 inhabitants. Today, it is of strategic importance due to its location at the intersection of the main arteries of the Kadıköy district. It consists of Dumlupinar, Egitim, Fikirtepe and Merdivenkoy neighbourhoods (Figure 1), and Mandira and Hizirbey on the parallel road axis.
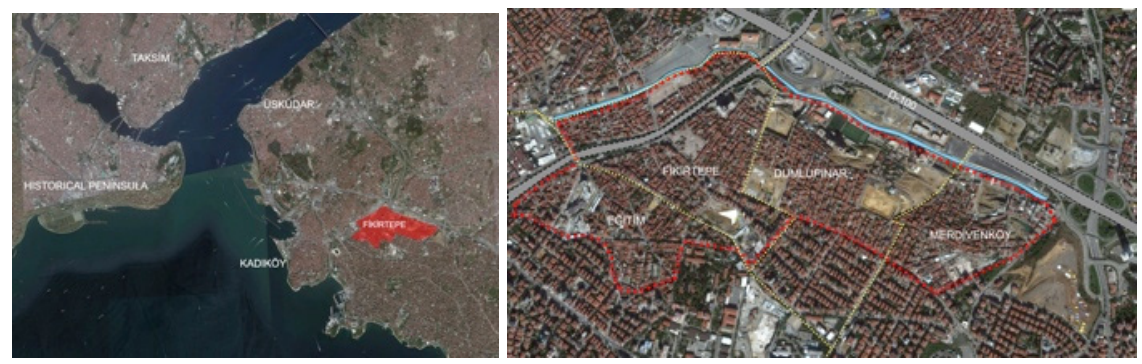

Figure 1: Kadıköy location and Fikirtepe neighbourhoods.

At the end of the 19th century, the construction of mansions started in the area although until the 1950s farms and gardens characterized the area. Later, two to three-storey self-build houses were built. Fikirtepe squatter region was once peripheral to the city, but has by now totally integrated into the greater urban settlement. In the neighbourhood of Egitim, there is some relatively modern housing.

Property ownership in Fikirtepe is based on title deeds issued to the squatters, through the amnesty laws, which in turn has resulted in an increase of selfconstructions. Fikirtepe is very attractive for investors due to its close proximity to the central business district of Kadıköy and to the high-income neighbourhoods along Bagdat Avenue. As a result of the transformation process, numerous construction companies have entered the area with proposals of megaprojects. 
This renewed interest among developers is driven by ever increasing housing prices, and ability of developers to access international financial markets.

The Fikirtepe transformation process became central on the agenda after the Istanbul Metropolitan Municipality (IMM) made a Master Plan of Istanbul in 2005 [39]. In 2010, the Earthquake Environmental Plan was approved by the IMM and the Urban Transformation Project was initiated [39]. IMM first increased the coefficient floor area ratio from 10 percent to 80 percent in 2011 , but later decreased it to 45 percent in 2012 [39]. In 2013, the urban transformation process was stopped but later Fikirtepe was included in the Urban Transformation Law 6306, which forced residents to agree with contractors [39]. In January 2014, the ministry took over authority from the municipality with the aim of accelerating the transformation process. In 2016, conflicts still existed between developers and squatters and between the IMM and Kadıköy Municipality [40].

At the beginning of the process, developers planned to build 50,000 attractive housing units in 54 plots [41]. However, as of mid-2016 no projects were completed. Since the new development plan allows the construction of a whole block, many developers and construction firms started to acquire and combine parcels to get the maximum allowed floor area.

When Fikirtepe was selected as a pilot development area, the the maximum allowed height was 40 stories. However, the IMM later restricted building heights to $80 \mathrm{~m}$ (27 floors) with a floor area ratio coefficient of four. As a result, developers began to slow down their construction plans. The Ministry has decided to widen the road axes, increase social facility areas, and change equivalence values of the the area ratio to attract more investors [42].

\section{Survey results and criticism of the urban transformation process in Fikirtepe squatter neighbourhood}

The Fikirtepe Urban Transformation Project has been criticized by both the residents and observers alike. To find out the underlying political, physical, social and economic aspects behind these criticisms, a field survey was carried out in the autumn 2015 . The questionnaire was answered by 51 respondents (63 percent male and 37 percent female).

\subsection{Social components}

According to the survey, 22 percent of the residents were not aware of the existence of an urban transformation project while and 51 percent have been living in Fikirtepe for more than 20 years. However, ties among residents started to weaken due to physical and social fragmentation. The traditional solidarity between neighbours has started to vanish, and with it the collective memory of the place (Figure 2). Nevertheless, 78 percent of respondents were satisfied with their relationship with other neighbours and 74 percent with their homes. 

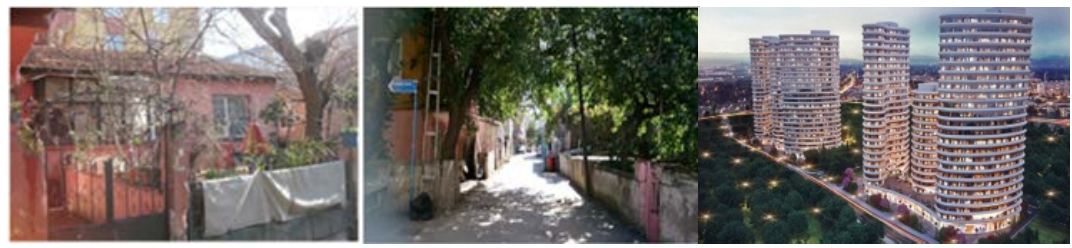

Figure 2: $\quad$ Social life in old neighbourhoods and in new projects in Fikirtepe.

Security has become an important issue since more than 1,500 housing units [43] had been abandoned for a long time. Refugees and other urban poor have occupied these empty houses. Crime rate is said to be on the increase, with 65 percent of respondents claiming the area was unsafe.

\subsection{Physical components}

The transformation of the Fikirtepe area is carried out through the demolition of existing structures, and the relocation of the neighbours in new buildings. However, half of the respondents are not satisfied with the on-going transformation of their built environment, and they are concerned that there is a risk of gentrification.

The protection of the existing architectural scale of low density housing, the urban morphology, and spatial identity are not being taken seriously enough. Lowdensity residential areas are being replaced with high-rise buildings with a low ratio of green areas. High-rise residences are located without any plan and this is destroying the silhouette of Kadıköy as well as its traditional urban morphology (Figure 3).
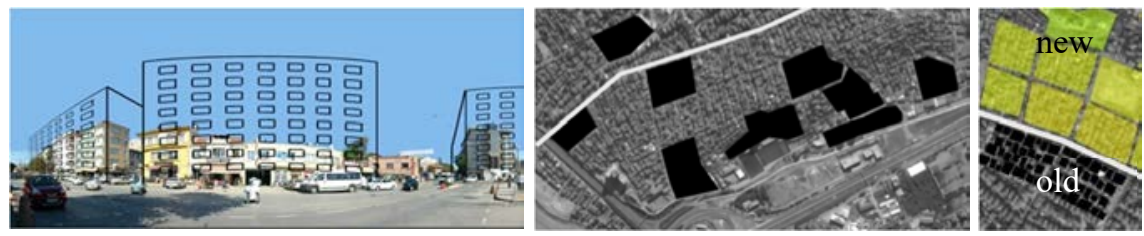

Figure 3: Old and new physical pattern in 2D and 3D in Fikirtepe (students' work).

More than half of the surveyed people (61 percent) reported that they do not want to live in the new residences in the future, and 28 percent of them would like to preserve the existing low density housing.

Developers have strongly encouraged gated communities and high-income apartments. This type of projects are neither compatible with the physical features of the squatter space nor with their lifestyle. This is reflected in the fact that 80 percent of respondents no longer wish to live in Fikirtepe because they think that they will not be able to afford to live in the "new" Fikirtepe and they prefer to move to a similar and close neighbourhood. 


\subsection{Political components}

In Fikirtepe, the transformation process had occurred differently from other districts of Istanbul. Here squatters and developers have been negotiating with each other over a period of time, under the supervision of Kadiköy Local Municipality, the IMM and the Ministry. However, TOKI, allegedly the main actor in this transformation process, has not been involved at all in these negotiations. This might explain why 57 percent of respondents considered that the transformation process was not progressing as it should. They think that residents and the society as a whole were not properly informed and that public administration, institutions, and private developers disregarded any need for transparency. Furthermore, 64 percent of respondents did not know how many square meters they will get from the developers.

There is a timing issue related to the transformation process. As a pilot project it was supposed to finish on schedule to be an example of good planning for other regions and neighbourhoods in Istanbul. However, during the last six years the development progressed very slowly and today there are no finished projects in Fikirtepe yet. Uncertainty and ambiguity created stress for residents with 73 percent responding that they do not have any idea where they will be living in the next five years.

There are differences among theories, legal systems and practices. The process has become uncertain with the change of rules. For instance, the floor area ratio was first set to 2.07 and then changed to 4.14 and later to 4.0, which affected the density of the area. Similarly, storey restriction of Fikirtepe pilot development area was not specified at first. The Istanbul Metropolitan Municipality restricted height of the buildings to 80 meters ( 27 floors). Before, construction was allowed up to 40 stories high. For this reason, developers slowed the construction hoping that the height limit would be increased again. Interestingly, 39 percent of respondents said that they do not have a clear idea about the future appearance of the "new" Fikirtepe.

\subsection{Economic components}

Although this kind of development projects are supposed to invigorate the local economy, this transformation process has become a way of generating unearned profit for developers, who seem to be the only beneficiaries. Usually there is a big gap between old and new residents' income. As for household composition and income, 39 percent of households consisted of five members, and 59 percent earned 2,000 Turkish liras or less per month. Shops, grocery stores and renters might lose their workspaces and incomes. Forty seven percent of all respondents reported that they were only tenants and therefore had no economic interest in this transformation process.

\section{Conclusions}

From our study of the Fikirtepe squatter district, certain conclusions can be drawn about urban transformation in Istanbul. 
Social components: Urban transformation projects should address social issues such as education, unemployment, poverty, crime rates, and social segregation in the area at stake. The interests of renters living in the affected areas should also be taken into account.

Physical/spatial components: High-rise or large-scale buildings should not be the only alternative to squatter settlements. Density is an important instrument for urban transformation. Quality and controlled density could help to achieve liveable environments. Open and green spaces are vital. Gentrification should be avoided in order to address the needs of the residents who lived in the area prior to transformation and their possible resettlement to other locations must be considered.

Economic components: Low cost and affordable housing schemes should be provided for both rental and purchase options. TOKI, local and central governments, and the private sector need to cooperate in order to build affordable, quality housing projects. Urban transformation can be used as an engine to develop the local economy, and not only the national economy. Multi-staged processes should be considered as plausible housing procurement alternatives.

Political components: A comprehensive housing policy is necessary in Turkey. The full impact of urban transformation projects needs to be studied and analysed carefully prior to construction to avoid the quick and fait accompli policies too often practiced in Turkey. Urban transformation projects need inputs from a variety of stakeholders. Legal and managerial structures should be developed in conjunction with the new policies. Local and central governments should ensure long-term leadership to prevent conflicts between stakeholders and developers during the transformation process.

\section{References}

[1] Mumford, L., The City in History, Penguin Books: New York, 1991.

[2] Smith, N., Gentrification, Border and Redevelopment of Urban Space. Topics in Gentrification of the City, eds N. Smith \& P. Williams, Routledge: London, pp. 29-55, 2007.

[3] Pacione, M., Urban Geography: A Global Perspective, Routledge: London, 2009.

[4] Gugler, J., The Urban Transformation of the Developing World, Oxford University Press: Oxford, 1996.

[5] Keleş, R., Urbanization, Housing and Squatter Settlement in Turkey, Cem Yayınevi: İstanbul, 2014.

[6] Davis, M., Planet of Slums, Verso: New York, 2006.

[7] Kartal, K., Created transmission of recourses between rural and urban by migrants and squatter housing. World Urban Planning Day First Turkish Urban Congress Proceedings, Ankara, pp. 267-294, 1981.

[8] Prunty, J., Dublin Slums, Irish Academic Press: Ireland, 1995.

[9] Wright, C.D., The Slums of Baltimore, Chicago, New York, and Philadelphia, Washington Press: Washington, 1894.

[10] Ranson, R., Healthy Housing, E\&FN Spon and WHO: London, 1991. 
[11] Drakakis-Smith, D., Slums and Squatters in Ankara. Town Planning Review, 47(3), pp. 225-240, 1977.

[12] Keles, R., Urban Policies, Image Publications: Istanbul, 2012.

[13] Devlet Planlama Teskilati (State Planning Organisation), Gecekondu Araştırması (Research on Squatter Housing), Sosyal Planlama Baskanligi (Directorate of Social Planning): Ankara, 1991.

[14] Bayraktar, E., Transformation of the City, Imak Ofset: Istanbul, 2013.

[15] Saunders, D., Arrival City, Pantheon: New York, 2011.

[16] Duyar-Kienast, U., The Formation of Gecekondu Settlements in Turkey, Lit Verlag: Münster, 2005.

[17] Rossi, A., The Architecture of the City, MIT Press: Cambridge, MA and London, 1982.

[18] Smailes, A.E., The Geography of Towns, Hutchinson University Library: London, 1953.

[19] Roberts, P. \& Sykes, H., Urban Regeneration, a Handbook, Sage Publications: London, Thousand Oaks and New Delhi, 2000.

[20] Stöhr, W., Regional policy at the crossroads: An overview. Regional Policy at the Crossroads: European Perspectives, eds L. Albrechts, F. Moulaert, P. Roberts \& E. Swyngedlouw, Jessica Kingsley: London, pp. 1-9, 1989.

[21] Lichfield, D., Urban Regeneration for the 1990s, London Planning Advisory Committee: London, 1992.

[22] Beswick, C.-A. \& Tsenkova, S., Overview of urban regeneration policies. Urban Regeneration: Learning from the British Experience, ed. S. Tsenkova, University of Calgary: Calgary, pp. 9-16, 2002.

[23] Gibson, M.S. \& Langstaff, M., An Introduction of Urban Renewal, G.B. Hutchinson: London, 1982.

[24] Bosselmann, Urban Transformation: Understanding City Design and Form, Island Press: Washington, Covelo and London, 2008.

[25] Thorn, D.C., The Transformation of Cities, Urban Theory and Urban Life, Palgrave: Basingstoke and New York, 2002.

[26] Decklerck, J., Building for Brussels, Architecture and Urban Transformation in European 44 Projects, Parantheses: Marseille, 2011.

[27] Chamber of Turkish Urban Planners. http://aura-istanbul.com/v2/tag/sehirplanlama/. (In Turkish.)

[28] Özkan, S., Traditionalism and vernacular architecture in the twenty-first century. Vernacular Architecture in the Twenty-First Century, eds L. Aquith \& M. Vellinga, Taylor \& Francis Group: London and New York, 2006.

[29] Zizek, S., The Sublime Object of Ideology, Verso: London, 1989.

[30] Balaban, O., Another present for Istanbul through meo-liberal reconstruction. Istanbul: Exceptional Situation of an Exclusive City (Istanbul: Müstesna Şehrin İstisna Hali), eds A. Çavdar \& P. Tan, Sel Publication: Istanbul, Chapter 2, 2013.

[31] Yang, Y., Sustainable urban transformation driving forces, indicators and processes. PhD dissertation, ETH Zurich, 2010. 
[32] Bayraktar, E., Housing, a Human Right (Bir Insanlik Hakki Konut), Boyut Publication Group: Istanbul, 2007.

[33] Tekeli, I., City, Right of Citizen, Urbanization and Urban Transformation, Tarih Vakfi Yurt Publications: Istanbul, 2011.

[34] Eraydin, A. \& Tasan-Kok, T., Resilience Thinking in Urban Planning, Springer: Dordrecht, Heidelberg, New York and London, 2013.

[35] TOKI, Squatter Settlement Transformation/Urban Renewal Projects (Gecekondu Dönüşüm/Kentsel Yenileme Projeleri), Republic of Turkey Prime Minister, TOKI Press: Istanbul, 2010.

[36] Alkiser, Y., Dulgeroglu-Yuksel, Y. \& Pulat-Gokmen, G., An evaluation of urban transformation projects. ArchNet-IJAR: International Journal of Architectural Research, 3(1), pp. 30-44, 2009.

[37] Özdoğan, M., Fikirtepe excavation. Istanbul University's Contributions to Archaeology in Turkey, ed. O. Belli, Istanbul University Rectorate Publications: Istanbul, pp. 32-33, 2001.

[38] Hür, A., Fikirtepe. Istanbul Encyclopedia (Dünden Bugüne İstanbul Ansiklopedisi), Tarih Vaqf Yurt Publications: Istanbul, 3, p. 315, 1994.

[39] Arkitera, 2016. www.arkitera.com/kose-yazisi/140/yeni-ucube-fikirtepe.

[40] Megaprojeleristanbul, 2016. http://megaprojeleristanbul.com/\#fikirtepekentsel-donusum-projesi.

[41] Milliyet Newspaper, 2016. http://ekonomi.milliyet.com.tr/fikirtepe-yiistanbulun/ekonomi/detay/1706800/default.htm.

[42] Ministry of Environment and Urbanization, 2016. www.csb.gov.tr.

[43] Ozturk, S. (Mayor of Kadıköy), 2016. https://selamiozturk.wordpress.com/ 2013/01/18/kentsel-donusum-ve-kadikoy/. 